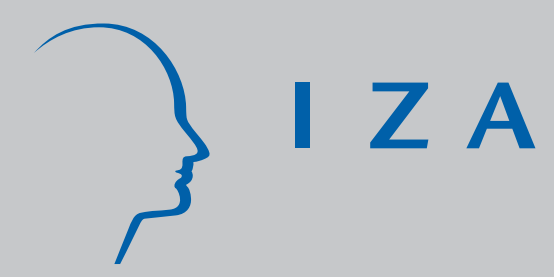

IZADP No. 4101

Workplace J ob Satisfaction in Britain: Evidence from Linked Employer-Employee Data

Getinet A. Haile

March 2009 


\title{
Workplace Job Satisfaction in Britain: Evidence from Linked Employer-Employee Data
}

\author{
Getinet A. Haile \\ Policy Studies Institute, \\ University of Mannheim and IZA
}

Discussion Paper No. 4101
March 2009

IZA

P.O. Box 7240

53072 Bonn

Germany

Phone: $+49-228-3894-0$

Fax: +49-228-3894-180

E-mail: iza@iza.org

\begin{abstract}
Any opinions expressed here are those of the author(s) and not those of IZA. Research published in this series may include views on policy, but the institute itself takes no institutional policy positions.

The Institute for the Study of Labor (IZA) in Bonn is a local and virtual international research center and a place of communication between science, politics and business. IZA is an independent nonprofit organization supported by Deutsche Post Foundation. The center is associated with the University of Bonn and offers a stimulating research environment through its international network, workshops and conferences, data service, project support, research visits and doctoral program. IZA engages in (i) original and internationally competitive research in all fields of labor economics, (ii) development of policy concepts, and (iii) dissemination of research results and concepts to the interested public.
\end{abstract}

IZA Discussion Papers often represent preliminary work and are circulated to encourage discussion. Citation of such a paper should account for its provisional character. A revised version may be available directly from the author. 


\title{
ABSTRACT
}

\section{Workplace Job Satisfaction in Britain: Evidence from Linked Employer-Employee Data}

\begin{abstract}
This paper examines the determinants of job satisfaction in Britain using nationally representative linked employer-employee data (WERS2004) and alternative econometric techniques. It uses eight facets of job satisfaction for the purpose. As well as underscoring the importance of accounting for unobserved workplace heterogeneity, the paper is able to highlight some new findings that relate to differential effects of dependent children and other dependents, type of employment contract and gaps between employees' skill and skills requirements of their job. Working long hours is found to be positively associated with intrinsic aspect of jobs. Public sector employment is positively associated with all facets of job satisfaction except satisfaction with pay.
\end{abstract}

JEL Classification: J28, I31

Keywords: job satisfaction, linked employer-employee data, Britain

Corresponding author:

Getinet A. Haile

Policy Studies Institute

50 Hanson Street

London W1W 6UP

United Kingdom

E-mail: g.haile@psi.org.uk

\footnotetext{
* Part of the work in this paper benefited from funding by the Economic and Social Research Council under grant RES-000-22-2465, which the author is grateful about. The Department of Trade and Industry, the Economic and Social Research Council, the Advisory, Conciliation and Arbitration Service and the Policy Studies Institute are acknowledged as the originators of the 2004 Workplace Employment Relations Survey data, and the Data Archive at the University of Essex as the distributor of the data. The National Centre for Social Research was commissioned to conduct the survey fieldwork on behalf of the sponsors. None of these organisations bears any responsibility for the author's analysis and interpretations of the data. The author would like to thank Alex Bryson, Michael White and Helen Bewley as well as participants of the $3^{\text {rd }}$ WERS users meeting and seminar participants at PSI and WBS for useful suggestions and comments on an earlier draft of the paper. The usual disclaimer applies.
} 


\section{Introduction}

Job satisfaction has traditionally been regarded as an important predictor of labour market behaviours of workers such as quit and absenteeism (Hammermesh 1997, Freeman 1978, Akerlof et al. 1988, Clark et al. 1998, Shields \& Price 2002, Kristensen \& Westergard-Nielsen 2004, Levy-Garbous et al. 2005).

Both in economics and other areas of social research job satisfaction has also been linked to individual well-being (Argyle 1989, Clark 1997, Warr 1999, Sousa-Poza and Sousa-Poza 2001, Kahneman \& Krueger 2006), job performance and productivity (e.g. Iaffaldano \& Muchinsky 1985), organisational performance (Ostroff 1992) and innovation (Shipton, et al. 2006).

While most previous studies sought to relate job satisfaction to a host of worker and job attributes (e.g. Clark 1996, Gazioglu and Tansel 2006), others have paid much attention to specific correlates of job satisfaction. These include, among others, gender (Clark 1997, Bender et al. 2005), age (Clark et al. 1996), wage (Borjas 1979, Clark et al. 1998, Clark 1999, Lydon \& Chevalier 2002), relative income (Clark and Oswald 1994, 1996), unions (Borjas 1979, Berger et al. 1983, Bryson et al. 2004; 2006), work environment (Idson 1990), work relations and management (Gazioglu \& Tansel 2004), and racial composition (Maume \& Sebastian 2007).

Though there exist a long list of research into different aspects of job satisfaction and/or its consequences, there remains growing interest in establishing the determinants of job satisfaction (Hammermesh 2001). Three important reasons could be cited in this respect. First, most of the research into the determinants of job satisfaction fails to account for unobserved individual- and/or workplace-level heterogeneity. One important lesson that research in labour economics, particularly involving linked employer-employee data, underscores is the importance of such unobserved factors in determining labour market outcomes (see, for example, Abowd et al. 1999). Job satisfaction as an outcome needs to account for unobserved heterogeneity to address such issues as worker sorting. Secondly, few studies have explored the determinants of various facets of job satisfaction and none looked at eight different such facets. This, despite the importance attached to exploring the various facets of job satisfaction (Rose 2001, Van Praag et al. 2002). Third, with few exceptions most studies on job satisfaction have not used correlates of job satisfaction relating both to the employee and the workplace; and the few studies that do so fail to account for clustering in the data, which is likely to lead to misleading 'statistically significant' effects.

This study attempts to fill the gap in the existing literature in at least two important ways. First, it uses linked employer-employee data and is able to account for a whole range of correlates of job satisfaction that relate to both the employee and the employer. ${ }^{1}$ Second, this study uses an empirical approach that is most suitable to the nested structure of the WERS2004 data, something that previous studies have not done. By accounting for unobserved workplace heterogeneity, the empirical methodology employed in this paper allows identifying unbiased influences of observable characteristics on job satisfaction. That the paper explores up to eight different facets of job satisfaction is a further strength of the study. This enables determining whether job satisfaction is a single entity, as much of the literature makes it out to be, or not.

The rest of the paper is organised as follows. In section 2, a brief review of the existing literature will be made. In section 3, a description of the data and variables used will be given. Section 4 sets out the empirical model used in the

${ }^{1}$ Some of these correlates are unique to the WERS 2004 data. 
estimation. In section 5 , the empirical results obtained will be discussed. The final section concludes the paper.

\section{Review of the literature}

The literature on job satisfaction has attempted to establish the determinants of job satisfaction by modelling reported job satisfaction as a function of a range of employee, employer and other job related correlates. The most commonly used correlates include level of pay, hours of work, demographic and human capital characteristics, work environment, and union membership. With regards to demographic and human capital characteristics; the weight of existing evidence suggests a U-shaped relationship between age and job satisfaction (Clark, 1996, Clark et al., 1996, Sloane \& Ward, 2001) although there is also some evidence that satisfaction increases with age (e.g. Shields \& Price, 2002). The existing evidence also suggests that women are more satisfied with their job than men (Clark, 1996, 1997; Clark \& Oswald, 1996, Blanchflower \& Oswald, 1999; Groot \& Brink, 1999, Sloane \& Williams, 2000) but based on a corss-national study SousaPoza \& Sousa-Poza (2000) find this to be largely an Anglo-Saxon phenomenon. Higher level of education is generally associated with lower level of job satisfaction (Clark, 1996, Clark \& Oswald, 1996, Clark et al., 1996). Blanchflower \& Oswald (2001) and Clark (1997) find some evidence attesting to higher levels of job satisfaction for married individuals but Shield \& Price (2002) find no such evidence. There is also some evidence relating to the effect of health condition on job satisfaction where Clark (1996) finds that health problems lead to lower level of job satisfaction.

In terms of job related characteristics, income is probably the most widely investigated correlate. Clark (1997) and Shields \& Price (2002) find that income is an important determinant of both overall job satisfaction and satisfaction with pay. Others, for example Clark and Oswald (1996), find weak correlation between absolute income and job satisfaction while Belfield and Harris (2002) find no evidence that links job satisfaction with absolute income. However, there seems a consensus on the link between 'relative' income and job satisfaction. ${ }^{2}$ A number of studies including Clark and Oswald (1996), Levy-Garboua \& Montmarquette (1997), Neumark \& Postlewaite (1998), Sloane \& Ward (2001), Hamermesh (2001), and Shield \& Price (2002) find relative income as having an effect on job satisfaction. Lydon \& Chevalier (2002), on the other hand, question the validity of the notion of 'relative' income and estimate a satisfaction equation that addresses issues of wage endogeneity, finding a strong effect of wages (current as well as future) on job satisfaction.

As well as income and/or wage, hours of work has been found to impact job satisfaction. Clark (1996) finds hours to have a significant negative effect on overall job satisfaction and an even stronger negative effect on satisfaction with pay. Union membership has, for the most part, been found to have a strong negative effect on job satisfaction (Freeman, 1978, Borjas, 1979, Meng, 1990, Miller, 199). However, accounting for endogeneous selection as well as individuals and firm level heterogeneity, Bryson et al. $(2004,2006)$ find no marked difference in job satisfaction between unionized and non-unionized workers. With regards to workplace size the evidence is that larger establishment size is associated with lower

2 In Clark and Oswald (1996) 'relative' income is taken as the average income level of workers with similar characteristics while Hammermesh (2001) regards 'relative' income as surprises that make an individual worker well off. 
level of satisfaction (Idson, 1990, Clark, 1997, Gazioglu \& Tansel, 2006). Not much evidence exists regarding the relationship between job satisfaction and workplace segregations of different sorts. Bender et al. (2005) look into gender segregation and its effect on job satisfaction. They conclude that previous evidence suggesting an increase in the level of job satisfaction of women as the share of women at the workplace increases was due to exclusion of important determinants of jobs satisfaction such as flexibility between work and home. Peccei and Lee (2005) imply that workgroup gender composition have a negative influence on job satisfaction (particularly for men). On the other hand, Fields and Blum (1997), also looking at the relationship between workgroup gender composition and job satisfaction, find both men and women working in gender-balanced groups to have higher levels of job satisfaction vis-à-vis their counterparts working in homogeneous groups. ${ }^{3}$ Maume and Sebastian (2007) explore the effect of workgroup racial composition on the job satisfaction of white workers drawing on a broad 2002 cross-section of workers in the US. ${ }^{4}$ They find that an increase in the number of minority coworkers affects the job satisfaction of whites adversely but the effect vanishes once they control for the characteristics of jobs.

The review in the preceding paragraphs highlights the mixed nature of the evidence as regards to the influence of age, gender, marital status, income, union status and workgroup composition on job satisfaction. This could be attributed to differences in the types of job satisfaction measures used (e.g. overall versus facet specific), the type of data used (e.g. employee related versus matched employeremployee), the range and extent of controls used (e.g. demographic versus others), the empirical methodology employed (e.g. with and without accounting for unobserved heterogeneity). This paper uses ( $i$ e eight different facet satisfaction measures that are likely to address measurement related sensitivities, (iv) linked employer-employee data that enable controlling for both employee- and workplacelevel influences, (iii) an empirical methodology that accounts for workplace-level unobserved heterogeneity. Alternative specifications of each of the satisfaction equations have also been estimated to assess the robustness of findings in this paper.

\section{Data and variables}

\subsection{Overview of the Data}

The data used in this paper come from the 2004 British Workplace Employment Relations Survey (WERS2004), which is one of the most authoritative sources of information on employment relations in Great Britain. It offers linked employer-employee data representative of all workplaces with five or more employees (Kersley et al., 2006). The survey covers a whole host of issues relating to both employers and employees, allowing the inclusion of an array of individual and

\footnotetext{
3 Other (sociological) studies of similar nature, for example Wharton and Baron (1987), also find men in mixed work settings to have lower job-related satisfaction and self-esteem and more jobrelated depression than men in either male- or female-dominated work settings and attribute this to the decline in quantity and quality of inter-group relations as groups become more balanced.

4 The supposition here is that work is fundamentally a 'social phenomenon' and that it is at the workplace, more than in other settings (such as neighbourhoods, schools, and churches) that intergroup interaction exists between minorities and, in this case, whites; thereby impacting individual job attitudes.
} 
workplace level attributes into the analysis undertaken. The estimation sub-sample used in this paper comprises of 18689 employees in 1531 workplaces. $^{5}$

\subsection{Definition of variables}

\subsubsection{Outcome variables}

The first important set of variables relates to WERS2004 survey questions that focus on employee job-related satisfaction. These questions monitor how satisfied employees are with eight different aspects of their job. The survey asked each employee to rate - on a five-point scale from 'very satisfied' to 'very dissatisfied' how satisfied they were with: (i) the sense of achievement they get from their work; (ii) the scope for using their own initiative; (iii) the amount of influence they have over their job; (iv) the training they receive; $(v)$ the amount of pay they receive; $(v i)$ their job security; (vii) their work itself and (viii) their involvement in decision making. I use each of these 8 variables as facet satisfaction outcome measures. Tables A1 and A2 in the Appendix report descriptive statistics and correlation matrix relating to the outcome variables, respectively.

\subsubsection{Control variables}

Three sets of control variables have been used in the empirical analysis conducted. The first set of variables is those obtained from the employee survey and relates to employees' demographic, human capital and job related characteristics. The second set of variables relates to characteristics pertaining to the workplace including establishment size, ownership structure and type of industry. Finally I also control for geographic area and travel-to-work area unemployment and vacancy rates as these may have some bearing on the workplace job satisfaction of employees. Table A3 in the appendix provides descriptive statistics on all controls used in the empirical analysis.

\subsubsection{Workplace practice and policy summary variables}

A slightly different set of controls that I account for and that is specific to the workplace relates to the type of policy and practice in place at the workplace. This is likely to have some influence on the job satisfaction of employees and necessitates controlling for. The WERS2004 data have extensive information on workplace management practice and policy, and some method of reducing this vast data is essential if arbitrary choices of items are to be avoided. To address these issues I do two things. First, I focus on a sub-set of carefully selected aspects of workforce management and policy variables that are thought to reflect genuine commitment towards employees, something expected to improve the job satisfaction of employees. I chose aspects of workplace management practices and policies that demonstrate commitment towards (i) equality, (ii) training and development of employees and (iii) provisions of flexibility. Secondly, I use factor analysis and construct three different summary measures reflecting equality, training and flexibility. ${ }^{6}$ The scores generated in this way are then used in the empirical analyses I conduct forming one version/specification of the models I estimate. Appendix Tables A4 - A6 provide the list of workplace practice and policy variables used and Factor analysis outputs Tables.

\footnotetext{
${ }^{5}$ This is from the original matched sample of 22451 employees in 1733 workplaces. The reduction in the final sample is the result of (i) missing values on any of the facet satisfaction outcome measures, (ii) missing values on any of the employee and workplace covariates and (iii) keeping only workplaces with at least two responding employees.

${ }^{6}$ The factor scores have been generated using standard Factor Analysis in SPSS.
} 


\section{A framework of analysis}

There are two important issue in relation to modelling responses to subjective well-being questions. The first of these issues is to do with assumptions regarding the distribution of subjective responses while the second issue is to do with the way unobserved heterogeneity is accounted for (Ferreri-i-Carbonell and Frijters, 2004). What is observed in the WERS2004 data is employees' response on eight different aspects of their job, $S_{i}$, representing some underlying continuous latent measures of facet satisfaction of the employees, $S_{i}^{*}$. $S_{i}$ assumes ordinal values in the data and is modelled ordinally in line with the empirical economics tradition, which is achieved using ordered probability models. ${ }^{7}$

Ordinal probability models have been widely been used widely in the literature. Nevertheless, not many studies address the issue of unobserved heterogeneity. ${ }^{8}$ The non-experimental nature of the study raises the second important issue in relation to modelling responses to subjective well-being questions. The particular employer-employee match at a workplace and the level of job satisfaction therein are unlikely to represent random phenomena, given employer and employee preferences. To the extent that this is the case, addressing the issue of non-randomness becomes crucial to avoid potentially biasing effects of unobserved heterogeneity. Because the WERS2004 data are linked with more than one employee selected from each workplace, some respondents share observed and unobserved workplace attributes. This violates the independence assumption that (ordinal) regression models assume (Hedeker and Gibbons, 1994).In this paper unobserved heterogeneity is accounted for by exploiting the nested structure of the WERS2004 data and by estimating random-effects ordered logit models. ${ }^{9}$ This is achieved by employing the multilevel modelling framework. Using the cluster option in simple regression would have been the simplest option. However, this won't allow estimating the parameters measuring (shared) unobserved attributes. Neither would this allow testing the significance of such influences. ${ }^{10}$ Estimating (workplace) fixed effects regression could have been an option too. However, the cluster (or workplace) dummy variables would be correlated with important workplace characteristics. Moreover, previous research has shown that attempts to estimate FE models with the cluster effects treated as dummy variables gives rise to inconsistent estimates of the ordinal and regression coefficients, in addition to possible incidental parameter problem (Crouchley, 1995).

To estimate the random-effects ordered logit models, the original fivescale responses have been converted into three-scale responses. The five-scale responses for the facets of job satisfaction are 'very satisfied', 'satisfied', 'neither satisfied

\footnotetext{
7 Responses given to subjective well-being questions are only comparable ordinally. Thus, if two employees give identical responses to a subjective well-being question, they will be assumed to derive similar levels of satisfaction on the particular aspect of their job. Nevertheless, it is important to stress the crucial role that employee expectation plays in determining such responses.

8 There are few exceptions such as Winkelmann \& Winkelmann (1998), Clark et al. (2006), Bryson et al. $(2004,2006)$.

9 WERS2004 data are cross-section data and would not allow accounting for employee-level unobserved heterogeneity. However, we employ the multilevel modelling framework to account for workplace-level unobserved heterogeneity.

10 The simplest way of addressing this is to use cluster option in a regression. However, this won't allow us to estimate parameters measuring (shared) unobserved attributes. Neither would this allow testing the significance of such influences.
} 
nor dissatisfied', 'dissatisfied' and 'very dissatisfied', which are converted into the threescales of satisfied, neither and dissatisfied by collapsing the first and the last two responses. Converting the original responses in this way avoids data thinning in the extreme scales that entails model convergence problem. ${ }^{11}$

The random-effects ordered logit model I estimate can be formulate as a threshold model with observed ordinal satisfaction responses $s_{i j}$ of employee $i$ in workplace $j$ generated from the latent continuous responses $s_{i j}^{*}$ as

$$
s_{i j}=\left\{\begin{array}{ccc}
1 & \text { if } & w_{i j}^{*} \leq \kappa_{1} \\
2 & \text { if } & \kappa_{1}<w_{i j}^{*} \leq \kappa_{2} \\
\vdots & & \vdots \\
M & \text { if } & \kappa_{M-1}<w_{i j}^{*}
\end{array}\right.
$$

The satisfaction response variable $s_{i j}$ could be assumed to take values $m$ with probability $p_{i j}(m)=\operatorname{Pr}\left(s_{i j}=m\right)$ and cumulative response probabilities $P_{i j}(m)=\operatorname{Pr}\left(s_{i j} \leq m\right)=\sum_{r=1}^{m} p_{i j}(r), \quad r=1, \ldots, m-1$, for the $m$ categories of ordinal outcome of $s_{i j}$. The cumulative probabilities can be given by $P_{i j}(m)=F\left(\kappa_{m}-\eta_{i j}\right), \quad m=1, \ldots, M-1$, where $F$ is the cumulative density function of the model residuals, $\varepsilon_{i j}$ that can also be expressed as $P_{i j}(m)=R\left[P_{i j}(m)\right]=\kappa_{m}-\eta_{i j}, \quad m=1, \ldots, M-1$, where $R=F^{-1}$ is the link function. Assuming the distribution of the model residuals for the latent satisfaction response, $s_{i j}^{*}$, to be logistic, the cumulative probabilities can be given by

$$
P_{i j}(m)=\operatorname{Pr}\left(\varepsilon_{i j} \leq \kappa_{m}-\eta_{i j}\right)=\frac{\exp \left(\kappa_{m}-\eta_{i j}\right)}{1+\exp \left(\kappa_{m}-\eta_{i j}\right)}
$$

or, alternatively as

$$
\log \left[\frac{P_{i j}(m)}{1-P_{i j}(m)}\right]=\log \left[\frac{\operatorname{Pr}\left(w_{i j} \leq m\right)}{1-\operatorname{Pr}\left(w_{i j} \leq m\right)}\right]=\kappa_{m}-\eta_{i j} \quad m=1, \ldots, M-1
$$

where $\kappa_{c}$ is the threshold parameter for categories $m=1, \ldots, M-1$ and $\eta_{i j}=\beta_{o j}+\sum_{l=1}^{L} \beta_{l j} X_{l i j}$. The general model can thus be given by

\footnotetext{
${ }^{11}$ I also estimate alternative models including: linear random effects models, which I estimate using the original five-scale responses, and random effects logit models estimated on binary outcomes measures that assume a value of 1 if a person reported to be satisfied or very satisfied and 0 otherwise. The linear random effects models allow checking whether the cardinality assumption makes much difference to the empirical findings in the paper. It is also argued that when the number of categories is large ( 5 or more) it may be possible to approximate the distribution by a normal distribution and applying multilevel linear models (Snijders and Bosker, 2004). All three models are estimated in STATA using STATA's multilevel facility and GLLAMM.
} 


$$
\log \left[\frac{\operatorname{Pr}\left(s_{i j} \leq m\right)}{1-\operatorname{Pr}\left(s_{i j} \leq m\right)}\right]=\kappa_{m}-\left(\beta_{o j}+\sum_{l=1}^{L} \beta_{l j} X_{l i j}\right)
$$

The vector $X$ represents $L$ covariates representing the whole array of covariates relating to employees, their workplaces and geographic location. Since the regression coefficients in equation (5) do not carry the subscript $m$, they do not vary across the ordinal categories. Crucially, the intercept term $\beta_{0 j}$ in equation (5) has a workplace random component so that $\beta_{0 j}=\beta_{00}+\xi_{0 j}$, where $\beta_{00}$ is the mean intercept and $\xi_{0 j}$ is the deviation of the establishment specific intercept $\beta_{0 j}$ from the mean. I make several important assumptions in this set up including: ( $\imath$ ) independence across the $j$ workplaces (level-2 units), (ii) normally distributed employee error terms $\left(\varepsilon_{i j} \mid x_{i j} \sim N(0, \theta)\right)$ with no correlation between error terms associated with any two different employees within a workplace, i.e. $\left(\operatorname{Cov}\left(\varepsilon_{i j}, \varepsilon_{i^{\prime} j}\right)=0\right.$ for $\left.i \neq i^{\prime}\right)$ and (iii) workplace level variations that are distributed normally and uncorrelated with individual/employee error terms, i.e. $\xi_{0 j} \mid x_{i j} \sim N(0, \psi) \& \operatorname{Cov}\left(\xi_{0 j}, \varepsilon_{i j}\right)=0$, where $\theta \equiv \operatorname{Var}\left(\varepsilon_{i j}\right) \& \psi \equiv \operatorname{Var}\left(\xi_{0 j}\right)$ (Hedeker and Gibbons, 1994; Crouchley, 1995; Snijders and Bosker, 2004; RabeHesketh and Skrondal, 2008)

\section{Empirical results and discussion}

Estimation results from the random-effects logit equations relating to the eight facets of job satisfaction outcome measures are reported in Tables 1 through 8. In each case, I estimate three different specifications of the models to be able to check for the robustness of the estimation results. A descriptive statistics of the eight facet satisfaction measures and a correlation matrix depicting the correlation structure among them are given in Appendix Tables A1 and A2. The correlation matrix shows that all measures of facet satisfaction are positively correlated. The observed correlation is stronger among the intrinsic facets of satisfaction including those between: (i) 'satisfaction with the sense of achievement' and 'satisfaction with the scope for using own initiative', (ii) 'satisfaction with the sense of achievement' and 'satisfaction with the amount of influence on the job', (iii) 'satisfaction with the sense of achievement' and 'satisfaction with involvement in decision making', and (vi) 'satisfaction with the amount of influence on the job' and 'satisfaction with the work itself. Previous findings have shown that 'satisfaction with the nature of work undertaken' is found to be particularly closely associated with other facet-specific satisfaction and with overall job satisfaction (Warr 1999).

Appendix Table A3 reports descriptive statistics on the regressors used in the modelling. These include both employee and workplace characteristics. Accordingly, women constitute slightly more than 50 per cent of employees in the estimation sample while those that are 50 or over make up a little over 25 per cent of employees. Some 68 per cent of employees are married and only 5 per cent are non-white. Some 18 per cent of employees have dependent children under seven years of age while 16 per cent of employees have dependants other than children under 7 years. The proportion of employees with disability stands at 12 per cent of employees in the final sample. Most employees $(92 \%)$ are on permanent contract and 79 per cent of employees are employed full-time. Nearly 50 per cent of 
employees work over 48 hours per week while 53 per cent of employees report that their skills do not match the skills requirements of their job. Some 36 per cent of employees in the final sample are found to be trade union members.

In terms of workplace characteristics, some 70 per cent of workplaces are private establishments. The proportion of workplaces that are sole establishments stands at 21 per cent, indicating that most workplaces are part of a multiestablishment setup. Establishment size in the final sample ranges between 5 and 7740 with an average size of 388.4 employees per establishment (with a standard deviation of 811.5$)$. Also, most workplaces $(82 \%)$ are urban based establishments. The reported descriptive statistics also includes the three summary measures of workplace practice/policy variables representing provisions of equality, training and flexibility at the workplace, which are obtained from Factor Analysis.

As stated earlier, I estimate three different specifications of the randomeffects ordered logit models for each of the eight facet satisfaction outcome measures. The first specification controls only for employee-level characteristics. The second specification makes a further control for establishment-level characteristics, including labour market characteristics in the establishment's locality. Finally, the third specification controls for influences relating to workplace policy and practice by incorporating the summary scores described earlier.

Estimation results reported in Tables 1 to 8 provide a number of interesting findings, which are discussed in detail the following paragraphs under two main headings - employee and establishment characteristics.

\section{Employee Characteristics}

Employee-related characteristics are found to be important determinants of facet satisfactions. Accordingly, being young ( $<30$ years of age) is negatively and significantly associated with most facet satisfaction measures vis-à-vis being middleage (40-49 years of age). The exceptions to this are 'satisfaction with training received' and 'satisfaction with job security', which are both found to be positively and statistically significantly associated with being young. In contrast, being old $(50+)$ is associated to be positively and significantly associated with most facet satisfaction measures. These findings are also consistent across the three models estimated. Thus, the estimation results in this paper suggest satisfaction increasing with age for the bulk of the facet satisfaction measures.

Being female is found to be positively and statistically significantly associated with five of the eight facet satisfaction measures. The exceptions to this are: 'satisfaction with the scope for using own initiative' and 'satisfaction with the amount of influence' - both of which become insignificant when workplace-level characteristics are controlled for - and 'satisfaction with involvement in decision making', which is found to be insignificant across the three specifications.

Being married is associated positively and statistically significantly with nearly all of the facet satisfaction measures while having dependent children is found to be associated positively and statistically significantly with four of the eight facet satisfaction measures, which are regarded to reflect the intrinsic nature of jobs. In contrast, having dependents other than children is found to be associated negatively and statistically significantly with nearly all facet satisfaction measures.

One of the most consistent finding in this paper is that relating to having a disability, which is negatively and statistically significantly associated with all facet satisfaction equations estimated. Having no academic qualification is found to be associated positively and statistically significantly with all facets of satisfaction except 'satisfaction with pay', where it is found to be positively and statistically 
significantly associated and 'satisfaction with involvement in decision making', where it is found to have a negative but statistically insignificant effect.

Having a permanent job/contract is found to have statistically significant effect in five of the eight facet satisfaction measures including 'satisfaction with the scope for using own initiative', 'satisfaction with the amount of influence over the job', 'satisfaction with the amount of training received' and 'satisfaction with job security', where it is found to be positively associated, and 'satisfaction with pay', where it is found to be associated negatively. What is unsurprising is the huge and highly significant effect of being on permanent contract on 'satisfaction with job security'. In contrast, being a full-time employee is found to have significant effect only in three of the facet satisfactions, namely 'satisfaction with pay', where it is found to be highly significant, 'satisfaction with job security' and 'satisfaction with the work itself.

Working long hours (over 48 hours per week) is found to be statistically significantly associated with all facet satisfaction measures except with 'satisfaction with pay'. What is noteworthy is that the positive and statistically significant associations are mostly with the intrinsic aspects of jobs including: 'satisfaction with achievement', 'satisfaction with taking own initiative', 'satisfaction with influence over the job', 'satisfaction with the work itself' and 'satisfaction with involvement in decision making'. In contrast, working long hours is found to be negatively and statistically significantly associated with extrinsic aspects of jobs including: 'satisfaction with the amount of training received', where it is found to be marginally significant, and 'satisfaction with job security'.

Gaps between employees' skills and the skill requirements of the jobs they do are found to be associated consistently with all facet satisfaction measures. As would be expected, such a gap is found to be associated negatively and statistically significantly with all the facet satisfaction measures. In terms of employee occupation, being in lower level occupational groups is found to be negatively and statistically significantly associated vis-à-vis being in the reference category of managerial occupation. Union membership is also found to have consistent and negative association with all facet satisfaction measures, where the effect is found to be negative.

\section{Workplace Characteristics}

In terms of workplace characteristics, the paper finds some interesting results. Accordingly, being in a private establishment is found to be associated positively and statistically significantly with all except the facet measures 'satisfaction with the amount of training received', 'satisfaction with job security' and 'satisfaction with the degree of involvement in decision making'. In contrast, working in a single/sole establishment is found to have positive and statistically significant association with all except the 'satisfaction with the level of training received' measure of facet satisfaction.

Workplace size is found to be associated negatively and statistically significantly in most equations estimated as could be seen from the second specifications of the models estimated. However, controlling for the type of practice and policy in place at the workplace seems to eliminate the negative effects in most of the equations estimated. This suggests that the presence of sound policy and practice at the workplace addressing some of the negative effects of establishment size effect on facets of satisfaction.

In terms of sector/industry of employment, being in the education and health sectors are found to be associated consistently positively and statistically 
significantly vis-à-vis being in the financial and business services industry in all of the equations estimated except the facet measure 'satisfaction with pay'. This may be a reflection of the role relative pay among the different sectors plays. Other fairly consistent industry related effects this paper finds relates to the sectors 'whole sale and retail trade' and 'public and community services' that are also found to be associated positively and statistically significantly with most of the facet satisfaction equations estimated. The construction sector is the only industrial sector found to have statistically significant association, vis-à-vis the financial and business industry, with regards to the facet measure 'satisfaction with pay'. None of the other industry sectors are associated with statistically significant effect with this facet satisfaction measure

The summary measures of workplace practice and policy are not found to have effects that are intuitive for the most part. The only exception to this is the summary measure on training and its association with satisfaction with the amount of training received. In this case, workplaces that score high in terms of the summary scores on training policy and practice I construct are found to lead to a positive and statistically significant effect on the satisfaction with the amount of training their employees receive. In all other cases, higher values of summary scores on provisions of equality, training and flexibility are found to lead to either negative and statistically significant effect or insignificant effects for each of the other facet satisfaction measures.

The unobserved workplace heterogeneity parameter is found to be highly significant pointing to the need for accounting for unobserved workplace influences in the type of data used in this study. As could be seen from the three specifications of the satisfaction equations estimated, the inclusion of workplace characteristics in the models estimated reduces the magnitude of the unobserved workplace heterogeneity parameter. However, the decline is only marginal necessitating accounting for unobserved workplace heterogeneity.

\section{Conclusion}

This paper attempted to establish empirically the determinants of job satisfaction using a linked employer-employee data (WERS2004) and employing a statistical technique that is best suited to analysing such data. It uses eight different measures of employee facet satisfaction for the purpose. As well as making extensive review of existing literature, the paper employs innovative statistical technique to establish the determinants of facets of satisfaction.

The paper assumes that responses to subjective well-being measures are comparable (only) ordinally and accounts for unobserved workplace-level heterogeneity, which is found to be highly significant in all equations estimated. The later is achieved by exploiting the nested structure of the WERS2004 data and estimating random-effects ordered logit models. Unobserved heterogeneity is ignored by much of the literature on job satisfaction, and this paper attempts to address this issue adequately. The WERS2004 data offer extensive information on employees, workplaces as well as policies and practices in place at the workplace allowing controlling for confounding factors extensively. Alternative specifications of each of the facet satisfaction equations have been estimated in this paper to check for robustness, which holds generally.

In terms of the main findings of the paper, having a disability is associated negatively and statistically significantly across all equations estimated. Having dependent children less than 7 years of age is found to be associated positively with 
many of the equations estimated while having other dependants is found to be associated negatively with most of the equations estimated. Having no academic qualification is found to be positively and significantly associated with nearly all of the equations estimated. The presence of gaps between employees' skills and the skill requirements of their job is found to be associated negatively and statistically significantly across all equations estimated. Being on a permanent contract is found to be positively and significantly associated with four of the equations estimated and is found to have large and highly significant effect on 'satisfaction with job security' as would be expected.

Working long hours (over 48 hours per week) is found to be positively and significantly associated with the intrinsic aspects of jobs including 'satisfaction with the sense of achievement', 'satisfaction with the scope for using own initiatives', 'satisfaction with the amount of influence over the job', 'satisfaction with the work itself and 'satisfaction with involvement in decision making'. In terms of the industry/sector of employment, being in the public services sector in general and the education and health sectors is found to be positively and statistically significantly associated with all facet satisfaction measures except 'satisfaction with pay' vis-à-vis being in the financial and business services sector. 
Table 1: Satisfaction with the sense of achievement from work

\begin{tabular}{|c|c|c|c|c|c|c|}
\hline & $\operatorname{Exp}(b)$ & z-stat & $\operatorname{Exp}(b)$ & z-stat & $\operatorname{Exp}(b)$ & z-stat \\
\hline Age $<30$ & 0.7699 & -5.01 & 0.7876 & -4.55 & 0.7862 & -4.59 \\
\hline Age30-39 & 0.9313 & -1.47 & 0.9511 & -1.03 & 0.9490 & -1.08 \\
\hline Age 50-59 & 1.3049 & 5.17 & 1.2810 & 4.81 & 1.2805 & 4.80 \\
\hline Age60+ & 2.2961 & 7.73 & 2.2325 & 7.45 & 2.2270 & 7.43 \\
\hline Female & 1.3274 & 6.87 & 1.2419 & 5.14 & 1.2429 & 5.16 \\
\hline Married & 1.1160 & 2.82 & 1.1217 & 2.95 & 1.1197 & 2.90 \\
\hline White & 0.8020 & -2.77 & 0.7894 & -2.94 & 0.7888 & -2.95 \\
\hline Children $<7$ yrs old & 1.0890 & 1.75 & 1.0885 & 1.74 & 1.0882 & 1.73 \\
\hline Other dependents & 0.8754 & -2.85 & 0.8681 & -3.02 & 0.8687 & -3.01 \\
\hline Disabled & 0.7848 & -4.72 & 0.7875 & -4.65 & 0.7892 & -4.61 \\
\hline No academic qualification & 1.2816 & 3.55 & 1.3107 & 3.85 & 1.3086 & 3.82 \\
\hline O-level & 1.1459 & 2.42 & 1.1679 & 2.75 & 1.1672 & 2.74 \\
\hline A-level & 1.0431 & 0.62 & 1.0662 & 0.94 & 1.0647 & 0.92 \\
\hline Other qualification & 1.1364 & 2.52 & 1.1395 & 2.56 & 1.1393 & 2.56 \\
\hline Missing qualification & 1.7377 & 3.28 & 1.7250 & 3.23 & 1.7190 & 3.21 \\
\hline On permanent contract & 1.0255 & 0.38 & 1.0665 & 0.97 & 1.0637 & 0.93 \\
\hline Full-time & 0.9564 & -0.91 & 1.0111 & 0.22 & 1.0129 & 0.26 \\
\hline Work over 48 hrs & 1.1763 & 4.15 & 1.1752 & 4.12 & 1.1754 & 4.13 \\
\hline Skill req. is higher & 0.6375 & -12.48 & 0.6417 & -12.31 & 0.6427 & -12.26 \\
\hline Skill req. is lower & 0.4353 & -11.05 & 0.4406 & -10.91 & 0.4421 & -10.86 \\
\hline Prof. occupations & 0.9586 & -0.55 & 0.8589 & -1.91 & 0.8554 & -1.96 \\
\hline Associate prof. or tech. & 0.8255 & -2.74 & 0.8074 & -3.03 & 0.8090 & -3.01 \\
\hline Admin \& secretarial & 0.5231 & -9.37 & 0.5293 & -9.16 & 0.5274 & -9.21 \\
\hline Skilled trades & 0.7481 & -3.33 & 0.7621 & -3.06 & 0.7579 & -3.12 \\
\hline Personnel services & 1.1114 & 1.15 & 0.8982 & -1.12 & 0.8998 & -1.10 \\
\hline Sales \& customer services & 0.4558 & -8.84 & 0.4686 & -7.88 & 0.4698 & -7.86 \\
\hline Process, plant, mach. op. & 0.4315 & -10.25 & 0.4646 & -9.08 & 0.4651 & -9.05 \\
\hline Elementary occupations & 0.4838 & -9.18 & 0.4857 & -8.93 & 0.4886 & -8.85 \\
\hline Trade union member & 0.7136 & -8.57 & 0.7206 & -7.78 & 0.7257 & -7.61 \\
\hline Log workplace age & & & 0.9829 & -0.92 & 0.9869 & -0.70 \\
\hline Private establishment & & & 1.1148 & 1.69 & 1.1305 & 1.91 \\
\hline Sole establishment & & & 1.1810 & 3.08 & 1.1437 & 2.40 \\
\hline No. of employees & & & 0.9999 & -2.67 & 1.0000 & -1.46 \\
\hline Manufacturing & & & 0.8270 & -2.52 & 0.8324 & -2.43 \\
\hline Construction & & & 1.1961 & 1.67 & 1.1586 & 1.37 \\
\hline Whole sale \& retail Trade & & & 1.2376 & 2.31 & 1.2324 & 2.25 \\
\hline Hotel, rest \& transport & & & 0.9733 & -0.32 & 1.0067 & 0.08 \\
\hline Public \& comm. services & & & 1.1764 & 2.06 & 1.2185 & 2.50 \\
\hline Education & & & 1.7688 & 5.79 & 1.7147 & 5.46 \\
\hline Health & & & 1.6251 & 5.50 & 1.7461 & 6.18 \\
\hline Prop. $(22+)$ on min. wage & & & 1.3801 & 1.30 & 1.3474 & 1.21 \\
\hline Prop. on customer service & & & 0.9173 & -0.76 & 0.9389 & -0.56 \\
\hline Urban area & & & 0.9213 & -1.49 & 0.9196 & -1.53 \\
\hline Unemp. to vacancy ratio & & & 0.9874 & -1.45 & 0.9867 & -1.53 \\
\hline Hpws (equality) & & & & & 0.9713 & -1.21 \\
\hline Hpws (training) & & & & & 1.0104 & 0.48 \\
\hline Hpws (flexibility) & & & & & 0.9160 & -3.64 \\
\hline _Cut11 (Cons) & -2.9943 & -22.31 & -2.8860 & -16.19 & -2.8518 & -15.99 \\
\hline _Cut12 (Cons) & -1.5862 & -11.98 & -1.4759 & -8.35 & -1.4416 & -8.14 \\
\hline$\sigma^{\wedge} 2$ (Workplace variance) & 0.4505 & 16.76 & 0.4151 & 15.31 & 0.4095 & 15.04 \\
\hline Log-Likelihood & -14065.4 & & -14005.9 & & -13998.7 & \\
\hline No. of employees & 18689 & & 18689 & & 18689 & \\
\hline No. of workplaces & 1531 & & 1531 & & 1531 & \\
\hline
\end{tabular}

Note: Reported results in this and subsequent Tables are all exponential coefficients 
Table 2: Satisfaction with the scope for using own initiative

\begin{tabular}{|c|c|c|c|c|c|c|}
\hline & $\operatorname{Exp}(b)$ & z-stat & $\operatorname{Exp}(b)$ & z-stat & $\operatorname{Exp}(b)$ & z-stat \\
\hline Age $<30$ & 0.8709 & -2.61 & 0.8834 & -2.32 & 0.8823 & -2.35 \\
\hline Age30-39 & 1.0215 & 0.43 & 1.0400 & 0.79 & 1.0391 & 0.77 \\
\hline Age 50-59 & 1.1211 & 2.22 & 1.1055 & 1.95 & 1.1048 & 1.94 \\
\hline Age60+ & 1.8492 & 5.91 & 1.8003 & 5.65 & 1.7949 & 5.62 \\
\hline Female & 1.0948 & 2.17 & 1.0398 & 0.91 & 1.0400 & 0.92 \\
\hline Married & 1.1833 & 4.29 & 1.1849 & 4.32 & 1.1844 & 4.31 \\
\hline White & 1.0120 & 0.15 & 0.9921 & -0.10 & 0.9888 & -0.14 \\
\hline Children $<7$ yrs old & 1.1022 & 1.94 & 1.1029 & 1.96 & 1.1030 & 1.96 \\
\hline Other dependents & 0.8869 & -2.56 & 0.8823 & -2.67 & 0.8827 & -2.66 \\
\hline Disabled & 0.7795 & -4.81 & 0.7830 & -4.73 & 0.7840 & -4.70 \\
\hline No academic qualification & 1.3065 & 3.76 & 1.3047 & 3.72 & 1.3012 & 3.68 \\
\hline O-level & 1.0658 & 1.11 & 1.0696 & 1.17 & 1.0685 & 1.15 \\
\hline A-level & 0.9533 & -0.69 & 0.9688 & -0.46 & 0.9687 & -0.46 \\
\hline Other qualification & 1.0748 & 1.39 & 1.0678 & 1.26 & 1.0684 & 1.27 \\
\hline Missing qualification & 1.7514 & 3.30 & 1.7221 & 3.20 & 1.7195 & 3.19 \\
\hline On permanent contract & 1.1565 & 2.25 & 1.1825 & 2.58 & 1.1823 & 2.58 \\
\hline Full-time & 1.0192 & 0.39 & 1.0593 & 1.18 & 1.0612 & 1.22 \\
\hline Work over 48 hrs & 1.2312 & 5.25 & 1.2315 & 5.24 & 1.2322 & 5.26 \\
\hline Skill req. is higher & 0.5537 & -16.11 & 0.5563 & -15.98 & 0.5568 & -15.96 \\
\hline Skill req. is lower & 0.4630 & -9.97 & 0.4678 & -9.84 & 0.4694 & -9.80 \\
\hline Prof. occupations & 0.6500 & -5.35 & 0.6090 & -5.98 & 0.6070 & -6.02 \\
\hline Associate prof. or tech. & 0.6559 & -5.66 & 0.6496 & -5.76 & 0.6496 & -5.76 \\
\hline Admin \& secretarial & 0.4422 & -11.13 & 0.4542 & -10.72 & 0.4533 & -10.74 \\
\hline Skilled trades & 0.5348 & -6.86 & 0.5246 & -6.94 & 0.5213 & -7.01 \\
\hline Personnel services & 0.6626 & -4.54 & 0.5710 & -5.92 & 0.5702 & -5.93 \\
\hline Sales \& customer services & 0.3694 & -10.79 & 0.3760 & -9.80 & 0.3758 & -9.80 \\
\hline Process, plant, mach. op. & 0.3141 & -13.40 & 0.3254 & -12.60 & 0.3241 & -12.62 \\
\hline Elementary occupations & 0.4218 & -10.35 & 0.4377 & -9.70 & 0.4370 & -9.70 \\
\hline Trade union member & 0.7615 & -6.86 & 0.8006 & -5.25 & 0.8052 & -5.10 \\
\hline Log workplace age & & & 0.9462 & -2.95 & 0.9485 & -2.82 \\
\hline Private establishment & & & 1.1792 & 2.61 & 1.1801 & 2.61 \\
\hline Sole establishment & & & 1.1416 & 2.45 & 1.1060 & 1.80 \\
\hline No. of employees & & & 0.9999 & -2.38 & 1.0000 & -1.69 \\
\hline Manufacturing & & & 0.9777 & -0.29 & 0.9710 & -0.38 \\
\hline Construction & & & 1.3318 & 2.61 & 1.3128 & 2.47 \\
\hline Whole sale \& retail Trade & & & 1.2333 & 2.25 & 1.2187 & 2.10 \\
\hline Hotel, rest \& transport & & & 0.8919 & -1.36 & 0.8975 & -1.27 \\
\hline Public \& comm. services & & & 1.1278 & 1.53 & 1.1461 & 1.73 \\
\hline Education & & & 1.5781 & 4.71 & 1.5698 & 4.62 \\
\hline Health & & & 1.5841 & 5.27 & 1.6296 & 5.47 \\
\hline Prop. $(22+)$ on min. wage & & & 1.3837 & 1.31 & 1.3412 & 1.19 \\
\hline Prop. on customer service & & & 0.9288 & -0.65 & 0.9379 & -0.56 \\
\hline Urban area & & & 0.9528 & -0.88 & 0.9504 & -0.93 \\
\hline Unemp. to vacancy ratio & & & 0.9849 & -1.75 & 0.9844 & -1.81 \\
\hline Hpws (equality) & & & & & 0.9552 & -1.89 \\
\hline Hpws (training) & & & & & 0.9999 & -0.01 \\
\hline Hpws (flexibility) & & & & & 0.9658 & -1.44 \\
\hline _Cut11 (Cons) & -2.9569 & -22.03 & -2.9296 & -16.47 & -2.9303 & -16.43 \\
\hline _Cut12 (Cons) & -1.6193 & -12.22 & -1.5904 & -9.01 & -1.5910 & -8.98 \\
\hline$\sigma^{\wedge} 2$ (Workplace variance) & 0.4330 & 15.76 & 0.4013 & 14.41 & 0.4001 & 14.36 \\
\hline Log-Likelihood & -13782.8 & & -13734.0 & & -13731.5 & \\
\hline No. of employees & 18689 & & 18689 & & 18689 & \\
\hline No. of workplaces & 1531 & & 1531 & & 1531 & \\
\hline
\end{tabular}


Table 3: Satisfaction with the amount of influence over the job

\begin{tabular}{|c|c|c|c|c|c|c|}
\hline & $\operatorname{Exp}(b)$ & z-stat & $\operatorname{Exp}(b)$ & z-stat & $\operatorname{Exp}(b)$ & z-stat \\
\hline Age $<30$ & 0.8716 & -2.90 & 0.8736 & -2.84 & 0.8718 & -2.88 \\
\hline Age30-39 & 1.0007 & 0.02 & 1.0102 & 0.23 & 1.0085 & 0.19 \\
\hline Age 50-59 & 1.1357 & 2.81 & 1.1225 & 2.55 & 1.1216 & 2.54 \\
\hline Age60+ & 1.7762 & 6.52 & 1.7353 & 6.25 & 1.7286 & 6.21 \\
\hline Female & 1.0823 & 2.13 & 1.0579 & 1.48 & 1.0585 & 1.50 \\
\hline Married & 1.0795 & 2.18 & 1.0834 & 2.28 & 1.0820 & 2.24 \\
\hline White & 0.8911 & -1.64 & 0.8738 & -1.90 & 0.8700 & -1.97 \\
\hline Children $<7$ yrs old & 1.0801 & 1.75 & 1.0820 & 1.79 & 1.0829 & 1.81 \\
\hline Other dependents & 0.9125 & -2.19 & 0.9106 & -2.24 & 0.9111 & -2.23 \\
\hline Disabled & 0.7785 & -5.36 & 0.7789 & -5.35 & 0.7805 & -5.31 \\
\hline No academic qualification & 1.3203 & 4.42 & 1.2895 & 4.02 & 1.2850 & 3.96 \\
\hline O-level & 1.1164 & 2.15 & 1.1041 & 1.93 & 1.1022 & 1.90 \\
\hline A-level & 0.9316 & -1.13 & 0.9378 & -1.03 & 0.9373 & -1.04 \\
\hline Other qualification & 1.0054 & 0.12 & 0.9933 & -0.15 & 0.9935 & -0.14 \\
\hline Missing qualification & 1.6306 & 3.43 & 1.5824 & 3.22 & 1.5770 & 3.19 \\
\hline On permanent contract & 1.1193 & 1.95 & 1.1275 & 2.08 & 1.1270 & 2.07 \\
\hline Full-time & 1.0049 & 0.11 & 1.0307 & 0.70 & 1.0332 & 0.75 \\
\hline Work over 48 hrs & 1.1295 & 3.46 & 1.1221 & 3.27 & 1.1228 & 3.28 \\
\hline Skill req. is higher & 0.6507 & -13.46 & 0.6528 & -13.37 & 0.6536 & -13.33 \\
\hline Skill req. is lower & 0.4633 & -11.08 & 0.4648 & -11.04 & 0.4668 & -10.98 \\
\hline Prof. occupations & 0.5373 & -9.06 & 0.5285 & -9.03 & 0.5263 & -9.09 \\
\hline Associate prof. or tech. & 0.5364 & -9.81 & 0.5377 & -9.72 & 0.5382 & -9.70 \\
\hline Admin \& secretarial & 0.4504 & -12.50 & 0.4617 & -12.07 & 0.4603 & -12.11 \\
\hline Skilled trades & 0.4760 & -9.31 & 0.4541 & -9.74 & 0.4497 & -9.85 \\
\hline Personnel services & 0.4755 & -9.68 & 0.4367 & -10.34 & 0.4361 & -10.36 \\
\hline Sales \& customer services & 0.3590 & -12.39 & 0.3545 & -11.57 & 0.3546 & -11.56 \\
\hline Process, plant, mach. op. & 0.3255 & -14.49 & 0.3254 & -14.08 & 0.3234 & -14.12 \\
\hline Elementary occupations & 0.4179 & -11.82 & 0.4299 & -11.22 & 0.4292 & -11.23 \\
\hline Trade union member & 0.6913 & -10.41 & 0.7434 & -7.88 & 0.7492 & -7.67 \\
\hline Log workplace age & & & 0.9540 & -2.76 & 0.9577 & -2.53 \\
\hline Private establishment & & & 1.2215 & 3.49 & 1.2252 & 3.54 \\
\hline Sole establishment & & & 1.1871 & 3.51 & 1.1354 & 2.51 \\
\hline No. of employees & & & 0.9999 & -3.52 & 0.9999 & -2.37 \\
\hline Manufacturing & & & 1.0663 & 0.91 & 1.0592 & 0.81 \\
\hline Construction & & & 1.4571 & 3.79 & 1.4267 & 3.57 \\
\hline Whole sale \& retail Trade & & & 1.3724 & 3.69 & 1.3496 & 3.47 \\
\hline Hotel, rest \& transport & & & 0.9543 & -0.60 & 0.9661 & -0.44 \\
\hline Public \& comm. services & & & 1.1912 & 2.43 & 1.2231 & 2.78 \\
\hline Education & & & 1.4130 & 3.98 & 1.4003 & 3.86 \\
\hline Health & & & 1.4813 & 5.05 & 1.5529 & 5.52 \\
\hline Prop. $(22+)$ on min. wage & & & 1.4848 & 1.77 & 1.4253 & 1.58 \\
\hline Prop. on customer service & & & 0.8884 & -1.12 & 0.9038 & -0.95 \\
\hline Urban area & & & 0.9500 & -1.03 & 0.9471 & -1.10 \\
\hline Unemp. to vacancy ratio & & & 0.9868 & -1.68 & 0.9862 & -1.76 \\
\hline Hpws (equality) & & & & & 0.9402 & -2.80 \\
\hline Hpws (training) & & & & & 0.9976 & -0.12 \\
\hline Hpws (flexibility) & & & & & 0.9459 & -2.53 \\
\hline _Cut11 (Cons) & -2.8525 & -23.80 & -2.7625 & -17.30 & -2.7569 & -17.23 \\
\hline _Cut12 (Cons) & -1.2385 & -10.48 & -1.1467 & -7.24 & -1.1408 & -7.19 \\
\hline$\sigma^{\wedge} 2$ (Workplace variance) & 0.4312 & 18.22 & 0.3961 & 16.62 & 0.3931 & 16.47 \\
\hline Log-Likelihood & -17059.80 & & -17002.32 & & -16996.12 & \\
\hline No. of employees & 18689 & & 18689 & & 18689 & \\
\hline No. of workplaces & 1531 & & 1531 & & 1531 & \\
\hline
\end{tabular}


Table 4: Satisfaction with training received on the job

\begin{tabular}{|c|c|c|c|c|c|c|}
\hline & $\operatorname{Exp}(b)$ & z-stat & $\operatorname{Exp}(b)$ & z-stat & $\operatorname{Exp}(b)$ & z-stat \\
\hline Age $<30$ & 1.2160 & 4.16 & 1.2334 & 4.45 & 1.2317 & 4.42 \\
\hline Age30-39 & 1.0061 & 0.14 & 1.0200 & 0.47 & 1.0197 & 0.46 \\
\hline Age 50-59 & 1.1913 & 3.99 & 1.1748 & 3.67 & 1.1758 & 3.69 \\
\hline Age60+ & 1.9472 & 7.98 & 1.9047 & 7.71 & 1.9109 & 7.75 \\
\hline Female & 1.2905 & 6.99 & 1.2192 & 5.34 & 1.2177 & 5.30 \\
\hline Married & 0.9765 & -0.69 & 0.9818 & -0.53 & 0.9822 & -0.52 \\
\hline White & 0.7798 & -3.48 & 0.7822 & -3.42 & 0.7858 & -3.35 \\
\hline Children $<7$ yrs old & 0.9946 & -0.13 & 0.9911 & -0.21 & 0.9923 & -0.18 \\
\hline Other dependents & 0.8496 & -3.97 & 0.8386 & -4.28 & 0.8384 & -4.29 \\
\hline Disabled & 0.8128 & -4.52 & 0.8126 & -4.52 & 0.8118 & -4.55 \\
\hline No academic qualification & 1.4913 & 6.51 & 1.5172 & 6.75 & 1.5280 & 6.86 \\
\hline O-level & 1.2942 & 5.21 & 1.3115 & 5.46 & 1.3171 & 5.54 \\
\hline A-level & 1.1595 & 2.44 & 1.1729 & 2.63 & 1.1750 & 2.66 \\
\hline Other qualification & 1.1985 & 4.14 & 1.1954 & 4.07 & 1.1979 & 4.12 \\
\hline Missing qualification & 1.8386 & 4.36 & 1.8168 & 4.27 & 1.8237 & 4.29 \\
\hline On permanent contract & 1.1396 & 2.24 & 1.1599 & 2.54 & 1.1585 & 2.52 \\
\hline Full-time & 0.9893 & -0.25 & 1.0188 & 0.43 & 1.0174 & 0.40 \\
\hline Work over 48 hrs & 0.9440 & -1.66 & 0.9419 & -1.72 & 0.9429 & -1.70 \\
\hline Skill req. is higher & 0.6597 & -13.41 & 0.6625 & -13.28 & 0.6626 & -13.27 \\
\hline Skill req. is lower & 0.3589 & -14.50 & 0.3616 & -14.41 & 0.3614 & -14.42 \\
\hline Prof. occupations & 0.9199 & -1.32 & 0.8876 & -1.84 & 0.8868 & -1.85 \\
\hline Associate prof. or tech. & 0.8320 & -3.20 & 0.8017 & -3.82 & 0.8025 & -3.81 \\
\hline Admin \& secretarial & 0.7526 & -4.88 & 0.7535 & -4.85 & 0.7543 & -4.83 \\
\hline Skilled trades & 0.7339 & -4.14 & 0.7653 & -3.54 & 0.7715 & -3.43 \\
\hline Personnel services & 1.0719 & 0.92 & 0.9023 & -1.31 & 0.9037 & -1.29 \\
\hline Sales \& customer services & 0.8695 & -1.71 & 0.9224 & -0.93 & 0.9225 & -0.93 \\
\hline Process, plant, mach. op. & 0.8180 & -2.68 & 0.8973 & -1.42 & 0.9088 & -1.25 \\
\hline Elementary occupations & 0.9851 & -0.21 & 0.9970 & -0.04 & 1.0063 & 0.09 \\
\hline Trade union member & 0.9232 & -2.21 & 0.9113 & -2.43 & 0.9105 & -2.45 \\
\hline Log workplace age & & & 0.9984 & -0.08 & 0.9961 & -0.20 \\
\hline Private establishment & & & 1.0865 & 1.26 & 1.1008 & 1.46 \\
\hline Sole establishment & & & 1.0965 & 1.69 & 1.1156 & 1.92 \\
\hline No. of employees & & & 1.0000 & -1.71 & 0.9999 & -2.09 \\
\hline Manufacturing & & & 0.7479 & -3.65 & 0.7613 & -3.43 \\
\hline Construction & & & 1.1357 & 1.17 & 1.1569 & 1.33 \\
\hline Whole sale \& retail Trade & & & 1.0114 & 0.12 & 1.0479 & 0.49 \\
\hline Hotel, rest \& transport & & & 1.0335 & 0.37 & 1.0620 & 0.67 \\
\hline Public \& comm. services & & & 1.1728 & 1.94 & 1.1788 & 2.00 \\
\hline Education & & & 1.2757 & 2.48 & 1.2784 & 2.50 \\
\hline Health & & & 1.8530 & 7.02 & 1.8722 & 6.98 \\
\hline Prop. $(22+)$ on min. wage & & & 0.9412 & -0.26 & 0.9610 & -0.17 \\
\hline Prop. on customer service & & & 0.9889 & -0.09 & 0.9718 & -0.24 \\
\hline Urban area & & & 0.9882 & -0.21 & 0.9848 & -0.27 \\
\hline Unemp. to vacancy ratio & & & 0.9901 & -1.11 & 0.9894 & -1.19 \\
\hline Hpws (equality) & & & & & 1.0158 & 0.63 \\
\hline Hpws (training) & & & & & 1.0696 & 2.98 \\
\hline Hpws (flexibility) & & & & & 1.0036 & 0.15 \\
\hline _Cut11 (Cons) & -1.5832 & -13.58 & -1.4484 & -8.71 & -1.4299 & -8.59 \\
\hline _Cut12 (Cons) & -0.2365 & -2.04 & -0.1002 & -0.60 & -0.0818 & -0.49 \\
\hline$\sigma^{\wedge} 2$ (Workplace variance) & 0.5984 & 25.74 & 0.5675 & 24.93 & 0.5628 & 24.71 \\
\hline Log-Likelihood & -18597.8 & & -18541.01 & & -18536.53 & \\
\hline No. of employees & 18689 & & 18689 & & 18689 & \\
\hline No. of workplaces & 1531 & & 1531 & & 1531 & \\
\hline
\end{tabular}


Table 5: Satisfaction with the amount of pay received

\begin{tabular}{|c|c|c|c|c|c|c|}
\hline & $\operatorname{Exp}(b)$ & z-stat & $\operatorname{Exp}(b)$ & z-stat & $\operatorname{Exp}(b)$ & z-stat \\
\hline Age $<30$ & 0.9182 & -1.85 & 0.9270 & -1.64 & 0.9262 & -1.65 \\
\hline Age30-39 & 1.0127 & 0.30 & 1.0157 & 0.37 & 1.0153 & 0.36 \\
\hline Age 50-59 & 0.9633 & -0.87 & 0.9601 & -0.94 & 0.9600 & -0.95 \\
\hline Age60+ & 1.3973 & 4.21 & 1.3726 & 3.99 & 1.3701 & 3.96 \\
\hline Female & 1.1250 & 3.27 & 1.1349 & 3.44 & 1.1351 & 3.44 \\
\hline Married & 1.1178 & 3.29 & 1.1146 & 3.21 & 1.1141 & 3.19 \\
\hline White & 1.1670 & 2.25 & 1.1576 & 2.12 & 1.1548 & 2.09 \\
\hline Children $<7$ yrs old & 1.0375 & 0.88 & 1.0334 & 0.78 & 1.0337 & 0.79 \\
\hline Other dependents & 0.9474 & -1.33 & 0.9503 & -1.26 & 0.9504 & -1.26 \\
\hline Disabled & 0.8093 & -4.61 & 0.8134 & -4.50 & 0.8141 & -4.48 \\
\hline No academic qualification & 0.8832 & -2.06 & 0.8888 & -1.94 & 0.8867 & -1.98 \\
\hline O-level & 0.9426 & -1.20 & 0.9487 & -1.07 & 0.9474 & -1.09 \\
\hline A-level & 0.9984 & -0.03 & 1.0106 & 0.17 & 1.0102 & 0.17 \\
\hline Other qualification & 0.9694 & -0.71 & 0.9705 & -0.69 & 0.9703 & -0.69 \\
\hline Missing qualification & 1.0381 & 0.28 & 1.0394 & 0.29 & 1.0384 & 0.29 \\
\hline On permanent contract & 0.8226 & -3.41 & 0.8295 & -3.26 & 0.8294 & -3.26 \\
\hline Full-time & 0.6602 & -9.88 & 0.6519 & -10.11 & 0.6528 & -10.08 \\
\hline Work over 48 hrs & 1.0510 & 1.46 & 1.0364 & 1.04 & 1.0367 & 1.05 \\
\hline Skill req. is higher & 0.5985 & -16.90 & 0.6006 & -16.79 & 0.6009 & -16.78 \\
\hline Skill req. is lower & 0.7386 & -4.35 & 0.7393 & -4.33 & 0.7406 & -4.31 \\
\hline Prof. occupations & 0.8056 & -3.45 & 0.7886 & -3.69 & 0.7875 & -3.71 \\
\hline Associate prof. or tech. & 0.6119 & -8.61 & 0.6088 & -8.65 & 0.6091 & -8.64 \\
\hline Admin \& secretarial & 0.5714 & -9.65 & 0.5643 & -9.82 & 0.5638 & -9.84 \\
\hline Skilled trades & 0.5737 & -7.46 & 0.5389 & -8.18 & 0.5364 & -8.23 \\
\hline Personnel services & 0.3593 & -13.96 & 0.3475 & -13.88 & 0.3475 & -13.88 \\
\hline Sales \& customer services & 0.5174 & -8.25 & 0.6104 & -5.78 & 0.6105 & -5.77 \\
\hline Process, plant, mach. op. & 0.5588 & -7.86 & 0.5375 & -8.20 & 0.5358 & -8.22 \\
\hline Elementary occupations & 0.5394 & -8.93 & 0.5267 & -9.13 & 0.5263 & -9.14 \\
\hline Trade union member & 0.7918 & -6.53 & 0.8264 & -5.06 & 0.8293 & -4.97 \\
\hline Log workplace age & & & 0.9643 & -1.85 & 0.9664 & -1.74 \\
\hline Private establishment & & & 1.1396 & 2.00 & 1.1399 & 2.00 \\
\hline Sole establishment & & & 1.2501 & 4.08 & 1.2131 & 3.37 \\
\hline No. of employees & & & 1.0000 & -1.78 & 1.0000 & -1.15 \\
\hline Manufacturing & & & 0.9439 & -0.72 & 0.9384 & -0.79 \\
\hline Construction & & & 1.2782 & 2.24 & 1.2624 & 2.11 \\
\hline Whole sale \& retail Trade & & & 0.9697 & -0.32 & 0.9556 & -0.47 \\
\hline Hotel, rest \& transport & & & 1.0854 & 0.92 & 1.0907 & 0.96 \\
\hline Public \& comm. services & & & 1.0168 & 0.20 & 1.0326 & 0.39 \\
\hline Education & & & 1.1143 & 1.10 & 1.1115 & 1.07 \\
\hline Health & & & 1.0052 & 0.06 & 1.0324 & 0.36 \\
\hline Prop. $(22+)$ on min. wage & & & 0.6523 & -1.80 & 0.6361 & -1.90 \\
\hline Prop. on customer service & & & 0.6272 & -3.91 & 0.6350 & -3.80 \\
\hline Urban area & & & 0.8524 & -2.82 & 0.8518 & -2.83 \\
\hline Unemp. to vacancy ratio & & & 1.0110 & 1.21 & 1.0107 & 1.18 \\
\hline Hpws (equality) & & & & & 0.9627 & -1.53 \\
\hline Hpws (training) & & & & & 0.9932 & -0.30 \\
\hline Hpws (flexibility) & & & & & 0.9695 & -1.24 \\
\hline _Cut11 (Cons) & -1.5865 & -13.91 & -1.7073 & -10.36 & -1.7046 & -10.31 \\
\hline _Cut12 (Cons) & -0.4871 & -4.29 & -0.6066 & -3.69 & -0.6039 & -3.66 \\
\hline$\sigma^{\wedge} 2$ (Workplace variance) & 0.6069 & 26.76 & 0.5827 & 26.12 & 0.5817 & 26.09 \\
\hline Log-Likelihood & -19347.48 & & -19302.96 & & -19301.3 & \\
\hline No. of employees & 18689 & & 18689 & & 18689 & \\
\hline No. of workplaces & 1531 & & 1531 & & 1531 & \\
\hline
\end{tabular}


Table 6: Satisfaction with job security

\begin{tabular}{|c|c|c|c|c|c|c|}
\hline & $\operatorname{Exp}(b)$ & z-stat & $\operatorname{Exp}(b)$ & z-stat & $\operatorname{Exp}(b)$ & z-stat \\
\hline Age $<30$ & 1.4028 & 6.44 & 1.4450 & 6.99 & 1.4439 & 6.97 \\
\hline Age30-39 & 1.1114 & 2.27 & 1.1309 & 2.64 & 1.1302 & 2.63 \\
\hline Age 50-59 & 1.1637 & 3.10 & 1.1489 & 2.84 & 1.1480 & 2.82 \\
\hline Age60+ & 2.1829 & 7.87 & 2.1308 & 7.63 & 2.1246 & 7.60 \\
\hline Female & 1.1719 & 3.86 & 1.1087 & 2.48 & 1.1088 & 2.49 \\
\hline Married & 1.0586 & 1.49 & 1.0672 & 1.70 & 1.0670 & 1.70 \\
\hline White & 0.9450 & -0.73 & 0.9543 & -0.60 & 0.9514 & -0.64 \\
\hline Children $<7$ yrs old & 0.9778 & -0.48 & 0.9765 & -0.50 & 0.9766 & -0.50 \\
\hline Other dependents & 0.8271 & -4.22 & 0.8176 & -4.48 & 0.8178 & -4.47 \\
\hline Disabled & 0.8096 & -4.15 & 0.8094 & -4.16 & 0.8102 & -4.14 \\
\hline No academic qualification & 1.2763 & 3.54 & 1.2943 & 3.74 & 1.2896 & 3.68 \\
\hline O-level & 1.0090 & 0.16 & 1.0215 & 0.39 & 1.0196 & 0.35 \\
\hline A-level & 1.0819 & 1.16 & 1.1016 & 1.43 & 1.1010 & 1.42 \\
\hline Other qualification & 1.0208 & 0.42 & 1.0185 & 0.38 & 1.0183 & 0.37 \\
\hline Missing qualification & 1.5589 & 2.81 & 1.5331 & 2.70 & 1.5312 & 2.69 \\
\hline On permanent contract & 3.5605 & 20.57 & 3.6479 & 20.97 & 3.6513 & 20.98 \\
\hline Full-time & 0.8023 & -4.44 & 0.8390 & -3.53 & 0.8404 & -3.50 \\
\hline Work over 48 hrs & 0.9284 & -1.93 & 0.9287 & -1.92 & 0.9287 & -1.92 \\
\hline Skill req. is higher & 0.7691 & -7.56 & 0.7752 & -7.34 & 0.7754 & -7.33 \\
\hline Skill req. is lower & 0.5436 & -8.10 & 0.5494 & -7.98 & 0.5507 & -7.94 \\
\hline Prof. occupations & 0.9560 & -0.63 & 0.8959 & -1.51 & 0.8944 & -1.53 \\
\hline Associate prof. or tech. & 0.8247 & -2.99 & 0.8070 & -3.33 & 0.8070 & -3.32 \\
\hline Admin \& secretarial & 0.8753 & -2.02 & 0.8898 & -1.77 & 0.8891 & -1.78 \\
\hline Skilled trades & 0.6935 & -4.40 & 0.7092 & -4.09 & 0.7046 & -4.17 \\
\hline Personnel services & 0.7308 & -3.67 & 0.6125 & -5.58 & 0.6116 & -5.59 \\
\hline Sales \& customer services & 0.8859 & -1.29 & 0.8788 & -1.31 & 0.8784 & -1.31 \\
\hline Process, plant, mach. op. & 0.8320 & -2.17 & 0.8995 & -1.23 & 0.8944 & -1.30 \\
\hline Elementary occupations & 0.9651 & -0.44 & 0.9641 & -0.44 & 0.9610 & -0.48 \\
\hline Trade union member & 0.7688 & -6.32 & 0.7589 & -6.39 & 0.7622 & -6.29 \\
\hline Log workplace age & & & 1.0447 & 1.67 & 1.0491 & 1.83 \\
\hline Private establishment & & & 0.9628 & -0.44 & 0.9582 & -0.49 \\
\hline Sole establishment & & & 1.4149 & 4.74 & 1.3416 & 3.83 \\
\hline No. of employees & & & 0.9999 & -2.13 & 0.9999 & -1.42 \\
\hline Manufacturing & & & 0.7504 & -2.75 & 0.7382 & -2.88 \\
\hline Construction & & & 1.6007 & 3.20 & 1.5721 & 3.06 \\
\hline Whole sale \& retail Trade & & & 2.1368 & 5.94 & 2.0790 & 5.68 \\
\hline Hotel, rest \& transport & & & 1.2862 & 2.15 & 1.2858 & 2.12 \\
\hline Public \& comm. services & & & 1.1770 & 1.50 & 1.2018 & 1.68 \\
\hline Education & & & 1.8414 & 4.68 & 1.8456 & 4.67 \\
\hline Health & & & 2.3245 & 7.31 & 2.4037 & 7.39 \\
\hline Prop. $(22+)$ on min. wage & & & 1.2345 & 0.68 & 1.1783 & 0.53 \\
\hline Prop. on customer service & & & 0.7769 & -1.63 & 0.7895 & -1.52 \\
\hline Urban area & & & 0.8802 & -1.69 & 0.8803 & -1.69 \\
\hline Unemp. to vacancy ratio & & & 1.0096 & 0.79 & 1.0093 & 0.77 \\
\hline Hpws (equality) & & & & & 0.9288 & -2.23 \\
\hline Hpws (training) & & & & & 0.9833 & -0.56 \\
\hline Hpws (flexibility) & & & & & 0.9625 & -1.15 \\
\hline _Cut11 (Cons) & -1.3095 & -10.21 & -0.8877 & -4.40 & -0.8895 & -4.39 \\
\hline _Cut12 (Cons) & 0.1265 & 0.99 & 0.5497 & 2.73 & 0.5481 & 2.71 \\
\hline$\sigma^{\wedge} 2$ (Workplace variance) & 0.9336 & 32.87 & 0.8553 & 31.63 & 0.8548 & 31.63 \\
\hline Log-Likelihood & -15750.45 & & -15654.92 & & -15652.11 & \\
\hline No. of employees & 18689 & & 18689 & & 18689 & \\
\hline No. of workplaces & 1531 & & 1531 & & 1531 & \\
\hline
\end{tabular}


Table 7: Satisfaction with the work itself

\begin{tabular}{|c|c|c|c|c|c|c|}
\hline & $\operatorname{Exp}(b)$ & z-stat & $\operatorname{Exp}(b)$ & z-stat & $\operatorname{Exp}(b)$ & z-stat \\
\hline Age $<30$ & 0.8491 & -3.08 & 0.8634 & -2.75 & 0.8629 & -2.76 \\
\hline Age30-39 & 0.9306 & -1.47 & 0.9456 & -1.14 & 0.9441 & -1.18 \\
\hline Age 50-59 & 1.2024 & 3.56 & 1.1805 & 3.20 & 1.1792 & 3.18 \\
\hline Age60+ & 2.2490 & 7.34 & 2.1937 & 7.11 & 2.1841 & 7.07 \\
\hline Female & 1.3951 & 8.02 & 1.3220 & 6.57 & 1.3242 & 6.61 \\
\hline Married & 1.0816 & 1.98 & 1.0868 & 2.10 & 1.0847 & 2.05 \\
\hline White & 1.0652 & 0.82 & 1.0465 & 0.59 & 1.0430 & 0.54 \\
\hline Children $<7$ yrs old & 1.1169 & 2.24 & 1.1189 & 2.27 & 1.1174 & 2.25 \\
\hline Other dependents & 0.8939 & -2.36 & 0.8906 & -2.44 & 0.8906 & -2.44 \\
\hline Disabled & 0.7893 & -4.57 & 0.7935 & -4.47 & 0.7953 & -4.42 \\
\hline No academic qualification & 1.5134 & 5.81 & 1.5322 & 5.94 & 1.5219 & 5.84 \\
\hline O-level & 1.2252 & 3.58 & 1.2386 & 3.76 & 1.2332 & 3.68 \\
\hline A-level & 1.1109 & 1.52 & 1.1300 & 1.77 & 1.1275 & 1.74 \\
\hline Other qualification & 1.1486 & 2.75 & 1.1466 & 2.70 & 1.1437 & 2.65 \\
\hline Missing qualification & 1.7065 & 3.16 & 1.6775 & 3.06 & 1.6666 & 3.02 \\
\hline On permanent contract & 0.9645 & -0.53 & 0.9943 & -0.08 & 0.9925 & -0.11 \\
\hline Full-time & 0.8208 & -3.89 & 0.8671 & -2.79 & 0.8684 & -2.76 \\
\hline Work over 48 hrs & 1.1730 & 4.05 & 1.1684 & 3.94 & 1.1672 & 3.92 \\
\hline Skill req. is higher & 0.6298 & -12.64 & 0.6326 & -12.52 & 0.6328 & -12.51 \\
\hline Skill req. is lower & 0.4629 & -10.03 & 0.4668 & -9.94 & 0.4676 & -9.92 \\
\hline Prof. occupations & 0.8834 & -1.64 & 0.8113 & -2.69 & 0.8092 & -2.73 \\
\hline Associate prof. or tech. & 0.8443 & -2.44 & 0.8301 & -2.67 & 0.8309 & -2.66 \\
\hline Admin \& secretarial & 0.5912 & -7.61 & 0.5985 & -7.40 & 0.5958 & -7.47 \\
\hline Skilled trades & 0.7182 & -3.85 & 0.7186 & -3.78 & 0.7103 & -3.91 \\
\hline Personnel services & 1.1225 & 1.25 & 0.9258 & -0.80 & 0.9273 & -0.78 \\
\hline Sales \& customer services & 0.5819 & -5.96 & 0.5791 & -5.55 & 0.5803 & -5.53 \\
\hline Process, plant, mach. op. & 0.5122 & -8.05 & 0.5299 & -7.42 & 0.5249 & -7.52 \\
\hline Elementary occupations & 0.5377 & -7.77 & 0.5266 & -7.87 & 0.5252 & -7.89 \\
\hline Trade union member & 0.7602 & -6.89 & 0.7716 & -6.10 & 0.7763 & -5.95 \\
\hline Log workplace age & & & 0.9962 & -0.20 & 1.0012 & 0.06 \\
\hline Private establishment & & & 1.2007 & 2.81 & 1.2053 & 2.87 \\
\hline Sole establishment & & & 1.1682 & 2.84 & 1.1328 & 2.20 \\
\hline No. of employees & & & 0.9999 & -2.47 & 1.0000 & -1.13 \\
\hline Manufacturing & & & 0.9018 & -1.36 & 0.9008 & -1.37 \\
\hline Construction & & & 1.1825 & 1.58 & 1.1377 & 1.21 \\
\hline Whole sale \& retail Trade & & & 1.4527 & 3.94 & 1.4203 & 3.68 \\
\hline Hotel, rest \& transport & & & 1.1166 & 1.29 & 1.1333 & 1.45 \\
\hline Public \& comm. services & & & 1.3080 & 3.37 & 1.3430 & 3.68 \\
\hline Education & & & 1.8030 & 5.95 & 1.7427 & 5.59 \\
\hline Health & & & 1.6499 & 5.61 & 1.7447 & 6.11 \\
\hline Prop. $(22+)$ on min. wage & & & 1.6695 & 1.92 & 1.6306 & 1.83 \\
\hline Prop. on customer service & & & 0.8295 & -1.61 & 0.8578 & -1.32 \\
\hline Urban area & & & 0.9365 & -1.18 & 0.9362 & -1.19 \\
\hline Unemp. to vacancy ratio & & & 0.9838 & -1.86 & 0.9837 & -1.88 \\
\hline Hpws (equality) & & & & & 0.9779 & -0.91 \\
\hline Hpws (training) & & & & & 0.9642 & -1.66 \\
\hline Hpws (flexibility) & & & & & 0.9235 & -3.25 \\
\hline _Cut11 (Cons) & -2.8384 & -21.22 & -2.5930 & -14.53 & -2.5757 & -14.41 \\
\hline _Cut12 (Cons) & -1.4205 & -10.77 & -1.1739 & -6.63 & -1.1566 & -6.52 \\
\hline$\sigma^{\wedge} 2$ (Workplace variance) & 0.4583 & 17.04 & 0.4206 & 15.42 & 0.4161 & 15.21 \\
\hline Log-Likelihood & -13719.31 & & -13664.69 & & -13658.53 & \\
\hline No. of employees & 18689 & & 18689 & & 18689 & \\
\hline No. of workplaces & 1531 & & 1531 & & 1531 & \\
\hline
\end{tabular}


Table 8: Satisfaction with involvement in decision-making

\begin{tabular}{|c|c|c|c|c|c|c|}
\hline & $\operatorname{Exp}(b)$ & z-stat & $\operatorname{Exp}(b)$ & z-stat & $\operatorname{Exp}(b)$ & z-stat \\
\hline Age $<30$ & 0.9879 & -0.26 & 0.9958 & -0.09 & 0.9940 & -0.13 \\
\hline Age30-39 & 1.0194 & 0.46 & 1.0307 & 0.72 & 1.0281 & 0.66 \\
\hline Age 50-59 & 1.0386 & 0.88 & 1.0261 & 0.60 & 1.0250 & 0.57 \\
\hline Age60+ & 1.3796 & 4.11 & 1.3418 & 3.75 & 1.3392 & 3.73 \\
\hline Female & 1.0374 & 1.02 & 0.9948 & -0.14 & 0.9958 & -0.12 \\
\hline Married & 1.0872 & 2.49 & 1.0923 & 2.63 & 1.0905 & 2.58 \\
\hline White & 1.0299 & 0.43 & 1.0078 & 0.11 & 1.0046 & 0.07 \\
\hline Children $<7$ yrs old & 1.0145 & 0.34 & 1.0186 & 0.44 & 1.0188 & 0.44 \\
\hline Other dependents & 0.8928 & -2.81 & 0.8897 & -2.90 & 0.8897 & -2.90 \\
\hline Disabled & 0.7934 & -5.11 & 0.7953 & -5.06 & 0.7972 & -5.01 \\
\hline No academic qualification & 0.9741 & -0.44 & 0.9721 & -0.47 & 0.9696 & -0.51 \\
\hline O-level & 1.0976 & 1.90 & 1.0984 & 1.91 & 1.0974 & 1.89 \\
\hline A-level & 1.0471 & 0.76 & 1.0575 & 0.93 & 1.0567 & 0.91 \\
\hline Other qualification & 1.0204 & 0.46 & 1.0165 & 0.37 & 1.0163 & 0.37 \\
\hline Missing qualification & 1.3218 & 2.15 & 1.3005 & 2.02 & 1.2960 & 2.00 \\
\hline On permanent contract & 0.9481 & -0.95 & 0.9677 & -0.58 & 0.9668 & -0.60 \\
\hline Full-time & 0.9563 & -1.08 & 0.9965 & -0.08 & 0.9984 & -0.04 \\
\hline Work over 48 hrs & 1.1458 & 4.01 & 1.1428 & 3.93 & 1.1432 & 3.94 \\
\hline Skill req. is higher & 0.6023 & -16.74 & 0.6039 & -16.67 & 0.6045 & -16.64 \\
\hline Skill req. is lower & 0.5047 & -9.97 & 0.5085 & -9.88 & 0.5101 & -9.84 \\
\hline Prof. occupations & 0.4518 & -12.22 & 0.4291 & -12.73 & 0.4275 & -12.79 \\
\hline Associate prof. or tech. & 0.4437 & -13.65 & 0.4464 & -13.49 & 0.4471 & -13.47 \\
\hline Admin \& secretarial & 0.3580 & -17.14 & 0.3691 & -16.59 & 0.3678 & -16.65 \\
\hline Skilled trades & 0.3060 & -15.57 & 0.3043 & -15.45 & 0.3018 & -15.54 \\
\hline Personnel services & 0.3777 & -13.19 & 0.3404 & -14.09 & 0.3413 & -14.07 \\
\hline Sales \& customer services & 0.3569 & -12.77 & 0.3410 & -12.41 & 0.3421 & -12.38 \\
\hline Process, plant, mach. op. & 0.2492 & -18.47 & 0.2623 & -17.42 & 0.2619 & -17.41 \\
\hline Elementary occupations & 0.3289 & -15.80 & 0.3381 & -15.18 & 0.3396 & -15.12 \\
\hline Trade union member & 0.6842 & -10.76 & 0.7168 & -8.97 & 0.7234 & -8.72 \\
\hline Log workplace age & & & 0.9567 & -2.37 & 0.9615 & -2.10 \\
\hline Private establishment & & & 1.0859 & 1.32 & 1.1018 & 1.56 \\
\hline Sole establishment & & & 1.2478 & 4.22 & 1.1790 & 3.03 \\
\hline No. of employees & & & 0.9999 & -4.74 & 0.9999 & -3.04 \\
\hline Manufacturing & & & 0.9116 & -1.21 & 0.9136 & -1.18 \\
\hline Construction & & & 1.3703 & 2.97 & 1.3197 & 2.62 \\
\hline Whole sale \& retail Trade & & & 1.2096 & 2.07 & 1.1898 & 1.88 \\
\hline Hotel, rest \& transport & & & 0.8762 & -1.55 & 0.9102 & -1.10 \\
\hline Public \& comm. services & & & 1.0592 & 0.73 & 1.1117 & 1.35 \\
\hline Education & & & 1.6043 & 5.02 & 1.5576 & 4.70 \\
\hline Health & & & 1.4343 & 4.36 & 1.5741 & 5.37 \\
\hline Prop. $(22+)$ on min. wage & & & 1.6360 & 2.15 & 1.5686 & 1.97 \\
\hline Prop. on customer service & & & 1.1871 & 1.50 & 1.2257 & 1.79 \\
\hline Urban area & & & 0.8720 & -2.54 & 0.8682 & -2.63 \\
\hline Unemp. to vacancy ratio & & & 0.9887 & -1.32 & 0.9876 & -1.46 \\
\hline Hpws (equality) & & & & & 0.9404 & -2.60 \\
\hline Hpws (training) & & & & & 1.0098 & 0.46 \\
\hline Hpws (flexibility) & & & & & 0.8972 & -4.57 \\
\hline _Cut11 (Cons) & -2.6505 & -22.96 & -2.7036 & -16.70 & -2.6704 & -16.50 \\
\hline _Cut12 (Cons) & -0.7458 & -6.55 & -0.7962 & -4.96 & -0.7626 & -4.75 \\
\hline$\sigma^{\wedge} 2$ (Workplace variance) & 0.5676 & 24.67 & 0.5287 & 23.53 & 0.5217 & 23.27 \\
\hline Log-Likelihood & -19065.5 & & -18995.15 & & -18982.29 & \\
\hline No. of employees & 18689 & & 18689 & & 18689 & \\
\hline No. of workplaces & 1531 & & 1531 & & 1531 & \\
\hline
\end{tabular}




\section{References}

Abowd JM, Kramarz F and Margolis DN (1999), High wage workers and high wage firms. Econometrica, 67 (2), 251-333.

Akrelof, GA, Rose, AK and Yellen JL (1988), Job Switching and job satisfaction in the US labour market. Brooking Papers on Economic Activity, 2, 495-582.

Argyle M (1989), The Social Psychology of Work. $2^{\text {nd }}$ edition, Penguin, Harmondsworth.

Belfield C and Harris R (2002), How well do theories of job matching explain variation in job satisfaction across educational level? Evidence for UK graduates. Applied Economics, 34, 535-0548.

Bender, KA, Donohue, SM and Heywood, JS (2005), Job Satisfaction and gender segregation. Oxford Economic Papers, 57, 479-496.

Berger, CJ, Olson CA and Boudreau, JW (1983), Effects of unions on job satisfaction: the role of work-related values and perceived rewards. Organizational Behaviour and Human Performance, 32, 289-324.

Blanchflower D., and Oswald A. (1999), Well-being, insecurity and the decline of American job satisfaction. Mimeo, Dartmouth College, USA.

Borjas G, (1979), Job satisfaction, wages and union. Human Resources, XIV, 21-40.

Bryson, A. Cappellari, L and Lucifora, C (2004), Does Union Membership Really Reduce Job satisfaction? British Journal of Industrial Relations, 42(3), 439-459.

Bryson, A. Cappellari, L and Lucifora, C (2005), Why so unhappy? The Effects of unionisation on job satisfaction. IZA discussion paper.

Bryson, A. Cappellari, L and Lucifora, C (2006), Why so unhappy? The Effects of unionisation on job satisfaction, Mimeo.

Clark AE (1999), Are wages habit-forming? Evidence from micro data. Journal of Economic Behavior and Organization, 39, 179-200.

Clark AE (2001), What really matters in a job? Hedonic measurement using quit data. Labour Economics, 8, 223-242.

Clark AE and Oswald AJ (1994), Unhappiness and unemployment. Economic Journal, 104, 648-659.

Clark AE, and Oswald A J (1996), Satisfaction and comparison income. Journal of Public Economics, 61, 359-381.

Clark AE, and Oswald AJ (1996), Satisfaction and comparison income. Journal of Public Economics, 61, 359-381.

Clark AE, Geogellis Y and Sanfey P (1997), Job satisfaction, wage changes and quits: Evidence from Germany. Research in Labour Economcis, 17, 95-121.

Clark AE, Oswald A, and Warr P (1996), Is job satisfaction U-shaped in age? Journal of Occupational and Organizational Psychology, 69, 57-81.

Clark, AE (1997), Job satisfaction and gender: Why are women so happy at work? Labour Economics, 4, 341-372.

Clark, AE, Georgellis, Y and Sanfey, P (1998), Job satisfaction, wage changes, and quits. Research in Labour Economics, 17, 95-121.

Clark, AE, Kristensen, N and Westergard-Nielsen (2006), Jo Satisfaction and Coworker Wage: Status or Signalling? Working paper, Paris-Jourdan Sciences Economiques (PSE).

Crouchley, R (1995), A random-effects model for ordered categorical data. Journal of the American Statistical Association, 90, 489-498.

Department of Trade and Industry (2005), Workplace Employment Relations Survey: Cross-Section, 2004 [computer file]. 1st ed. Colchester: The Data Archive [distributor], 21 December 2005. SN: 5294. 
Easterlin RA (2001), Income and happiness: Towards a unified theory. Economic Journal, 111, July, 465-484.

Ferrer-i-Carbonell, A. and Frijters, P., (2004), How important is methodology for the estimates of the determinants of happiness. The Economic Journal, 114, 641-659.

Freeman, RN (1978), Job satisfaction as an economic variable. American Economic Review, 68, 2, 135-141.

Frey B and Stutzer A (2002), What can economist learn from happiness research? Journal of Economic Literature, 40, 402-435

Galdeano AS (2001), Gender differences in job satisfaction and labour market participation: UK evidence from propensity score. Mimeo, EUI.

Gazioglu S. and Tansel A (2004), Job satisfaction, work environment and relations with managers in Britain. ERC working paper in economics, 03/04.

Gazioglu S. and Tansel A (2006), Job satisfaction in Britain: individual and job related factors. Applied Economics, 38, 1163-1171.

Groot W and van den Brink H (1999), Job satisfaction and preference drift. Economic Letters, 63, 363-367.

Haile, GA and Nguyen, AN (2002), Comparison income and job satisfaction: Evidence from GSOEP and NELS. Mimeo, Department of Economics, Lancaster University.

Hamermesh D (1977), Economic aspects of job satisfaction. In Ashenfelter O. and Oates W. (eds), Essays in Labor Market Analysis. Toronto: John Wiley\&Son.

Hamermesh D (2001), The changing distribution of job satisfaction. Human Resources, 36 (1), 1-30.

Hausman J, Abrevays J, and Scott-Morton, FM (1998), Misclassification of the Dependent Variable in a Discrete-Response Setting. Journal of Econometrics, 87, 239-269.

Iaffaldano, MT and Muchinsky, PM (1985), Job Satisfaction and Job Performance: A Meta-Analysis. Psychological Bulletin, 97 (2), 251-273.

Idson, TL (1990), Establishment size, job satisfaction and the structure of work. Applied Economics, 22, 1007-10018.

Kahneman, D and Krueger AB (2006), Developments in the Measurement of Subjective Well-Being. Journal of Economic Perspective, 20 (1), 3-24.

Kersley B., Alpin C., Forth J., Bryson A., Bewley H., Dix G. and Oxenbridge S. (2006), Inside the Workplace: Findings from the 2004 Workplace Employment Relations Survey. Routledge, London and New York

Kristensen, N and Westergard-Nielsen (2004), Does Low Job Satisfaction Lead to Job Mobility? IZA Discussion Paper No. 1026.

Levy-Garboua L and Montmarquette C (1997), Reported job satisfaction: What does it mean? Cirano, Canada.

Levy-Garboua L, Montmarquette C and Simonnet V (2001), Job satisfaction and quits: Theory and evidence from the German socioeconomic panel. Cirano, Canada.

Lydon R and Chevalier A (2002), Estimates of the effect of wages on job satisfaction. Centre for Economic Performance, LSE.

Maume DJ and Sebastian R (2007), Racial Composition of Workgroups and Job Satisfaction among Whites. The ANNALS of the American Academy of Political and Social Sciences, 609, 85-103.

McBride M (2001), Relative-income effects on subjective well-being in the crosssection. Journal of Economic Behavior and Organization, 45, 251-278. 
Ostroff, C (1992), The Relationship Between Satisfaction, Attitudes, and Performance: An Organization Level Analysis. Journal of Applied Psychology, 77 (6), 963-974.

Rodriguez, G and Goldman, N (2001), An Assessment of Estimation Procedures for Multilevel Models with Binary Responses. Journal of the Royal Statistical Society. Series A (Statistics in Society), 158 (1), 73-89.

Rodriguez, G and Goldman, N (2001), Improved Estimation Procedures for Multilevel Models with Binary Response: A Case-Study. Journal of the Royal Statistical Society. Series A (Statistics in Society), 164 (2), 339-355.

Rose M (2005), Job Satisfaction in Britain: Coping with Complexity. British Journal of Industrial Relations, 43 (3), 455-467.

Rose, M (2001), Disparate measures in the workplace ... Quantifying overall job satisfaction. Paper presented at the 2001 British Household Panel Survey Research Conference, Colchester, UK.

Shields M and Price S (2002), Racial harassment, job satisfaction and intentions to quit: Evidence from British Nursing profession. Economica, 69, 295-362.

Shipton HJ, West, MA, Parkes, CL and Dawson, JF (2006), When promoting positive feelings pays: Aggregate job satisfaction, work design features, and innovation in manufacturing organisations. European Journal of $W$ ork and Organizational Psychology, 15 (4), 404-430.

Skrondal, A. and Rabe-Hesketh (2004), Generalised Latent V ariable Modelling: Multilevel, Longitudinal, and Structural Equation Models. Chapman \& Hall/CRC.

Sloane PJ and Williams H (2002), Job satisfaction, comparison earnings and gender. Labour, 14, 473-502.s

Snijders, T. and Bosker, R. (2004), Multilevel Analysis: An introduction to basic and advanced multilevel modelling. Sage Publications Ltd, London

Sousa-Poza A and Sousa-Poza A (2000), Taking Another Look at the Gender/JobSatisfaction Paradox. KYKLOS, 53, 135-152.

Sousa-Poza A and Sousa-Poza A (2000), Well-being at work: a cross-national analysis of the levels and determinants of job satisfaction. Journal of Socioeconomics, 29, 517-538.

Usui, E (2006), Job Satisfaction and the Gender Composition of Jobs. Mimeo, Economics Department, Wayne State University.

Van Praag BMS, Frijter P, and Ferrer-Carbonell A (2003), The anatomy of subjective well-being. Journal of Economic Behavior and Organization, 51, 29-49.

Winkelmann L and Winkelmann R (1998), Why are the unemployed so unhappy? Evidence from panel data. Economica, 65, 1-15.

Wooldridge, J. M. (2002), Econometric Analysis of Cross Section and Panel Data. Massachusetts Institute of Technology. 


\section{Appendix}

Table A1: Descriptive statistics on LHS/satisfaction variables $(\mathrm{N}=18689)$

\begin{tabular}{lrrrr}
\hline \multicolumn{1}{c}{ Facet Satisfaction } & \multicolumn{1}{c}{ Mean } & Std. Dev. & Min & Max \\
\hline Achievement & 2.611 & 0.661 & 1 & 3 \\
Initiative & 2.625 & 0.657 & 1 & 3 \\
Influence & 2.443 & 0.724 & 1 & 3 \\
Training & 2.282 & 0.808 & 1 & 3 \\
Pay & 1.961 & 0.872 & 1 & 3 \\
Job security & 2.476 & 0.745 & 1 & 3 \\
Work itself & 2.633 & 0.645 & 1 & 3 \\
Decision & 2.172 & 0.765 & 1 & 3 \\
\hline
\end{tabular}

Table A2: Correlation matrix of satisfaction measures

$(\mathrm{N}=18689)$

1. Sense of achievement

\begin{tabular}{llllllll}
1 & 2 & 3 & 4 & 5 & 6 & 7 & 8 \\
1 & & & & & & & \\
0.56 & 1 & & & & & & \\
0.52 & 0.66 & 1 & & & & & \\
0.30 & 0.30 & 0.36 & 1 & & & & \\
0.21 & 0.21 & 0.26 & 0.28 & 1 & & & \\
0.27 & 0.26 & 0.31 & 0.31 & 0.25 & 1 & & \\
0.62 & 0.47 & 0.47 & 0.30 & 0.22 & 0.30 & 1 & \\
0.38 & 0.43 & 0.51 & 0.36 & 0.31 & 0.29 & 0.36 & 1 \\
\hline
\end{tabular}

2. Scope for using own init.

3. Amount of influence you've

4. Training you receive

5. Amount of pay you receive

6. Job security

7. Involvement in decision making

Table A3: Descriptive statistics of the RHS variables

\begin{tabular}{lcccc}
\hline Variable & Mean & Std. Dev & Min & Max \\
\hline Employee characteristics & & & & \\
Age $<30$ & 0.215 & 0.411 & 0 & 1 \\
Age30-39 & 0.256 & 0.436 & 0 & 1 \\
Age50-59 & 0.218 & 0.413 & 0 & 1 \\
Age60+ & 0.042 & 0.201 & 0 & 1 \\
Female & 0.525 & 0.499 & 0 & 1 \\
Married & 0.683 & 0.465 & 0 & 1 \\
White & 0.948 & 0.222 & 0 & 1 \\
Children <7yrs old & 0.182 & 0.386 & 0 & 1 \\
Other dependents & 0.161 & 0.367 & 0 & 1 \\
Disabled & 0.118 & 0.323 & 0 & 1 \\
No academic qual. & 0.149 & 0.356 & 0 & 1 \\
O-level & 0.230 & 0.421 & 0 & 1 \\
A-level & 0.091 & 0.287 & 0 & 1 \\
Other qualification & 0.325 & 0.468 & 0 & 1 \\
Missing qualification & 0.014 & 0.116 & 0 & 1 \\
On permanent contract & 0.922 & 0.268 & 0 & 1 \\
Full-time & 0.789 & 0.408 & 0 & 1 \\
Work over 48 hrs & 0.471 & 0.499 & 0 & 1 \\
Skill req. is higher & 0.530 & 0.499 & 0 & 1 \\
Skill req. is lower & 0.048 & 0.214 & 0 & 1 \\
Prof. occupations & 0.123 & 0.328 & 0 & 1 \\
Associate prof. or tech. & 0.166 & 0.372 & 0 & 1 \\
Admin \& secretarial & 0.187 & 0.390 & 0 & 1
\end{tabular}


Skilled trades

Personnel services

Sales \& customer services

Process, plant, mach. op.

Elementary occupations

Trade union member

Workplace characteristics

Log workplace age

Private establishment

Sole establishment

No. of employees

Manufacturing

Construction

Whole sale \& retail Trade

Hotel, rest \& transport

Public \& comm. services

Education

Health

Prop. $(22+)$ on min. wage

Prop. in customer service

Local area characteristics

Urban area

Unemployment to vacancy ratio

Workplace policy \& practice summary measures

Hpws (equality)

Hpws (training)

Hpws (flexibility)

No. of employees

No. of establishments

\begin{tabular}{|c|c|c|c|}
\hline 0.068 & 0.251 & 0 & 1 \\
\hline 0.088 & 0.284 & 0 & 1 \\
\hline 0.065 & 0.246 & 0 & 1 \\
\hline 0.077 & 0.267 & 0 & 1 \\
\hline 0.101 & 0.302 & 0 & 1 \\
\hline 0.359 & 0.480 & 0 & 1 \\
\hline 3.252 & 1.133 & 0 & 6.802 \\
\hline 0.695 & 0.460 & 0 & 1 \\
\hline 0.210 & 0.408 & 0 & 1 \\
\hline 388.4 & 811.5 & 5 & 7740 \\
\hline 0.156 & 0.363 & 0 & 1 \\
\hline 0.051 & 0.221 & 0 & 1 \\
\hline 0.093 & 0.290 & 0 & 1 \\
\hline 0.091 & 0.288 & 0 & 1 \\
\hline 0.157 & 0.364 & 0 & 1 \\
\hline 0.122 & 0.327 & 0 & 1 \\
\hline 0.155 & 0.362 & 0 & 1 \\
\hline 0.014 & 0.083 & 0 & 1 \\
\hline 0.106 & 0.233 & 0 & 1 \\
\hline 0.824 & 0.381 & 0 & 1 \\
\hline 3.396 & 2.399 & 0 & 10 \\
\hline 0.132 & 0.922 & -2.498 & 1.191 \\
\hline 0.067 & 0.986 & -1.599 & 2.708 \\
\hline 0.043 & 0.983 & -2.352 & 2.276 \\
\hline
\end{tabular}

